\title{
SIMULATION OF THE VOLCANIC ASH DISPERSION DURING THE JUNE 2019 SINABUNG ERUPTION
}

\author{
Rista Hernandi Virgianto ${ }^{a}$, Alia Rahmi Nasution ${ }^{b}$ \\ ${ }^{a}$ Department of Climatology, School of Meteorology, Climatology and Geophysics (STMKG), Jl. Perhubungan I No. 5, \\ Pondok Betung, Pondok Aren, Tangerang Selatan 15221, Indonesia \\ ${ }^{b}$ Agency for Meteorology, Climatology and Geophysics (BMKG), Jl. Angkasa 1 No.2, Kemayoran, Jakarta 10610, Indonesia
}

\section{ARTICLE INFO}

\section{Article history:}

Received: 21 April 2021

Accepted: 11 June 2021

Published: 25 June 2021

\section{Keywords:}

Dispersion; Sinabung Eruption; Volcanic Ash; WRF-Chem

\section{Corresponding author:}

Rista Hernandi Virgianto

School of Meteorology, Climatology, and Geophysics (STMKG), Tangerang Selatan, Indonesia

Email: rista.virgianto@stmkg.ac.id

\begin{abstract}
The eruption of Sinabung on June 9, 2019, was categorized as a red code in the warning report for flights. Volcanic ash from volcanic eruptions is a serious threat in the world of aviation with the most dangerous ash particles are 6-10 $\mu \mathrm{m}$ and $37 \mu \mathrm{m}$ in diameter. To enrich our understanding and modeling performances of the volcanic ash dispersion for the Sinabung eruption case, it is necessary to simulate the dispersion of volcanic ash in those particular sizes to see its distribution which can impact flight routes. The method used was the analysis of the direction and dispersion of the particular volcanic ash using Weather Research Forecast-Chemistry (WRF-Chem) and compared it with the volcanic ash warning information on flight routes issued by Volcanic Ash Advisory Centers (VAAC)-Darwin. In general, WRF-Chem can simulate the distribution of volcanic ash from the eruption of Sinabung at the two-particle sizes at different heights, and found the difference in the distribution direction of the two groups of the particle sizes. Comparison results with warning information from VAAC-Darwin and previous study, WRF-Chem simulation shows a good concordance in the dispersion direction.
\end{abstract}

Copyright (C) 2021 The Authors This open access article is distributed under Creative Commons Attribution (CC-BY) 4.0 International license

\section{Introduction}

Volcanic ash from volcanic eruptions as a threat to aviation safety has been extensively studied in various studies (Casadevall, 1994; Gordeev \& Girina, 2014; Guffanti \& Tupper, 2015; Miller, 1999; Prata \& Rose, 2015; Song et al., 2014). Dunn (2012) stated that the particle size of volcanic ash with a diameter of $6-10 \mu \mathrm{m}$ and $37 \mu \mathrm{m}$ could endanger the safety of aviation. The size of the volcanic ash particles that may be collected in the aircraft's environmental control system (ECS) is about $6-10 \mu \mathrm{m}$, if these particles exist in high concentration it can damage the ECS ducts and change the air distribution in the system which impacts both the engine and passengers. The particle size of volcanic ash that entered and could affect aircraft engine performance is around $37 \mu \mathrm{m}$. Volcanic ash particles that enter the engine will melt at a temperature of $800^{\circ} \mathrm{C}$ and will cause damage to the engine (Prata \& Rose, 2015), the temperature of the aircraft engine, or the so-called turbine inlet temperature (TIT) ranges from $1,238 \mathrm{~K}$ or $1,010^{\circ} \mathrm{C}$. Thus, the dispersion analysis of the two mentioned particle sizes deserves consideration for the data providers as consideration for decision making.

Volcanic ash dispersion modeling has been widely studied using various models, i.e. Lagrangian particle dispersion FLEXPART model (Stohl et al., 2011), Lagrangian stochastic NAME model (Devenish et al., 2012; Saxby et al., 2018), Eulerian FALL3D model (Folch et al., 2012), Hybrid Single-Particle Lagrangian Integrated Trajectory (HYSPLIT) model (Crawford et al., 2016; Lee et al., 2014; Tadini et al., 2020), and Weather Research Forecast-Chemistry (WRF-Chem) model (Egan et al., 2020; Steensen et al., 2013; Stenchikov et al., 2017; Webley et al., 2012). 
Table 1. Distribution of volcanic ash particle size in WRF-Chem

\begin{tabular}{ll}
\hline WRF Var & Diameter of particles \\
\hline vash_1 & $1-2 \mathrm{~mm}$ \\
vash_2 & $0.5-1 \mathrm{~mm}$ \\
vash_3 & $0.25-0.5 \mathrm{~mm}$ \\
vash_4 & $125-250 \mu \mathrm{m}$ \\
vash_5 & $62.5-125 \mu \mathrm{m}$ \\
vash_6 & $31.25-62.5 \mu \mathrm{m}$ \\
vash_7 & $15.625-31.25 \mu \mathrm{m}$ \\
vash_8 & $7.8125-15.625 \mu \mathrm{m}$ \\
vash_9 & $3.9065-7.8125 \mu \mathrm{m}$ \\
vash_10 & $<3.9 \mu \mathrm{m}$ \\
\hline${ }^{a}$ Source: Stuefer et al., 2012 &
\end{tabular}

Most of the research on the dispersion of volcanic ash in Indonesia relies on satellites data to analyze the ash dispersion (Fatkhuroyan \& Wati, 2017; Pandjaitan et al., 2016), this causes dispersion studies with regard to particle size is very limited because satellites have limitations in distinguishing the size of volcanic ash, even in some cases satellites are unable to identify volcanic ash on when there is cloud growth (Ryan \& Pratama, 2019). Thus, other methods are needed to analyze the dispersion of volcanic ash in more detail.

One of the methods that can be used to distinguish volcanic ash particles in certain sizes is the WRFChem model (Steensen et al., 2013; Webley et al., 2012). WRF-Chem is able to provide information on the distribution of volcanic ash with a diameter of $2 \mathrm{~mm}$ to less than $3.9 \mu \mathrm{m}$ which is divided into 10 size ranges (Stuefer et al., 2012). Table 1 shows the range of particle sizes provided by WRF-Chem. In addition, WRF-Chem can display the direction and dispersion at different heights (Wati et al., 2017).

The utilization of WRF-Chem on volcanic eruption cases in Indonesia has been applied to Barujari and Merapi eruption (Wati et al., 2017; Yudistira et al., 2020). The case of the Barujari eruption on 4 November 2015 was investigated by analyzing the results of the WRF-Chem parameter vash_10 and the Himari-8 satellite product, it was concluded that the WRF-Chem product was able to provide a more complete and clearer explanation for volcanic ash dispersion (Wati et al., 2017). Research on the Merapi eruption on 27 March 2020 showed the dispersion of volcanic ash in 10 size ranges, and it was found that vash_7 to vash_9 was close to the results of the report from Darwin Volcanic ash Advisory Center (VAAC) (Yudistira et al., 2020). However, from these two studies were found limited explanation regarding the two sizes of volcanic ash that are most dangerous for flight activities (Dunn, 2012). Therefore, it is necessary to do further research on these two groups of particle sizes.

The 9 June 2019 Sinabung eruption analysis using Himawari satellite imagery was done before by Pratama et al. (2019). The detection of the dispersion of large-size volcanic ash in the eruption of Mount Sinabung can be detected properly using the Himawari-8 satellite imagery. This study was focused to simulate the volcanic ash dispersion of the Sinabung eruption on 9 June 2019 that was categorized as a red code for a warning report on the aviation sector from Volcano Observatory Notice for Aviation (VONA). The red code indicates that the eruption is estimated to have had an altitude of more than $6,000 \mathrm{~m}$. Analysis needs to be done by considering the two-particle sizes that are most dangerous to the world of aviation, they are 6-10 $\mu \mathrm{m}$ and $37 \mu \mathrm{m}$ particles size in diameter, to see how dangerous this eruption is so that it is categorized as red code. Based on Table 1, the parameters that were analyzed in this study were vash_6 which represents the $37.5 \mu \mathrm{m}$ particles, and vash_8 along with vash_9 which represents the $6-10 \mu \mathrm{m}$ particles. Therefore, this study will give a better understanding in simulating the particular groups of volcanic ash that have a significant impact on aviation, especially in the Sinabung eruption.

\section{Methods}

\subsection{WRF-Chem model}

The WRF-Chem model is a non-hydrostatic mesoscale weather model capable of simulating particle transport and feedback along with meteorological parameters (Grell et al., 2005). Grell et al. (2005) stated that in actual conditions there is a combination of physical and chemical processes, which chemical elements can affect meteorological conditions such as the interaction of aerosols with cloud 


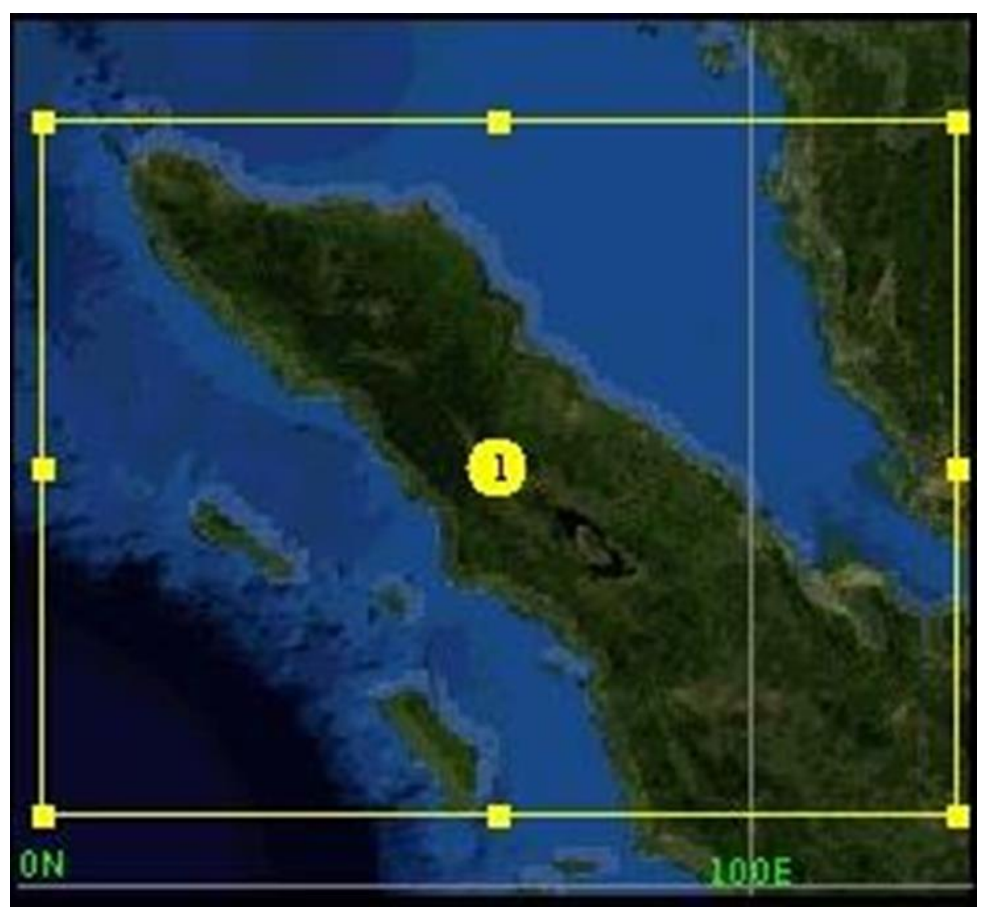

Figure 1. Domain used in WRF-Chem

condensation. Likewise, meteorological parameters, such as wind, will influence the elevation of the volcanic ash column (Bursik, 2001).

This study uses the WRF-Chem model to simulate the eruption ash dispersion, then the results were displayed using the GrADS (Grid Analysis and Display System). The data used in this research is the final analysis (FNL) data from NCEP (The National Centers for Environmental Prediction), the gridded global observation data for analysis was used as the initial and boundary meteorological conditions for the WRF-Chem simulation. The data were obtained from https://rda.ucar.edu/datasets/ds083.2/, with a 6-hour temporal resolution and a spatial resolution of $0.25^{\circ} \times 0.25^{\circ}$.

\subsection{Model configuration and analyzes}

The volcanic ash dispersion model requires input data called Eruption Source Parameters, this input contains information on the eruption column height, total mass, eruption duration, and particle distribution (Mastin et al., 2009). The domains used in WRF-Chem are as shown in Figure 1, with the domain configuration in Table 2. The configuration of the physics and chemistry options in the WRFChem model used in this study is shown in Table 3. The WRF-Chem simulation started at 18 UTC on 6 June 2019 and ended at 24 UTC on 9 June 2019. We used the first 52 hours as spin-up time and started the analyses at 00 UTC on 9 June 2019.

In this study, we analyzed the dispersion of two groups of volcanic ash particle sizes that are potentially harmful to aviation, i.e. particles of $36 \mu \mathrm{m}$ that represented by vash_6, and the 6-10 $\mu \mathrm{m}$ that represented by vash_8 and vash_9. In addition, we added vash_8 and vash_9 (vash_8-9) to combine those parameters to get the representation of the 6-10 $\mu \mathrm{m}$ particles. We evaluated the wind speed and direction at a significant level from WRF-Chem based on Upper-air Radio-sounding data from Kualanamu Airports, Medan (3.56N\&98.68E) collected on 9 June 2019 at 00 and 12 UTC. In addition, we evaluated the ash dispersion based on the VAAC-Darwin report and study done by Pratama et al. (2019) that utilized the satellite-based observation from Himawari.

\section{Results and Discussion}

The comparison between the wind speed and direction of the WRF-Chem simulations with upperair data (Table 4) at the same point, i.e. Kualanamu Airport, show that in general, the WRF-Chem model shows a good performance in simulating wind direction and speed in important layers except in $700 \mathrm{mb}$ at $00 \mathrm{UTC}$ and $600 \mathrm{mb}$ at $12 \mathrm{UTC}$. The WRF-Chem model is also capable of simulating higher wind speeds than lower ones. 
Table 2. Domain configurations used in this study

\begin{tabular}{ll}
\hline Parameters & Configurations \\
\hline e_we (number of grids in west-east direction) & 100 \\
e_sn (number of grids in south-north direction) & 100 \\
geographical data resolutions & $2 \mathrm{~m}$ \\
dx (grid distance in the west-east direction) & 6000 \\
dy (grid distance in the south-north direction) & 6000 \\
map projection & Mercator \\
ref_lat (the latitude of the center domain) & -8.34 \\
ref_lon (the longitude of the center domain) & 115.50 \\
time steps & $36 \mathrm{~s}$ \\
\hline
\end{tabular}

Table 3. Chemistry and physics options used in this study

\begin{tabular}{ll}
\hline Parameters & Options \\
\hline Chemistry & Volcanic ash falls and concentration only \\
Anthropogenic emissions & GOCART simple emissions \\
Biogenic emissions & No biogenic emissions \\
Biomass burning emissions & Include biomass burning emissions and plume rise calculation \\
Aerosol Optical Properties & $\begin{array}{l}\text { Aerosol optical properties calculated based upon volume } \\
\text { approximation }\end{array}$ \\
& Turn on \\
Gas phase chemistry & Turn on \\
Aerosol chemistry & Feedback from the aerosols to the radiation schemes turned on \\
Feedback from the aerosol & Turn on \\
Sub grid convective transport & Grell 3D \\
Cumulus scheme & Lint et al. Scheme \\
Microphysics & RRTMG scheme \\
Shortwave radiation & RRTMG scheme \\
Longwave radiation & Noah land surface model \\
Land surface model & MM5 similarity \\
Surface-layer & Yonsei University scheme \\
Boundary-layer &
\end{tabular}

The WRF-Chem model simulations show that the volcanic ash dispersion of vash_6 (Figure 2) moved westward at an altitude of $700 \mathrm{mb}$, and at an altitude of $250 \mathrm{mb}$ the volcanic ash dispersion moved to the southwest. The analysis of the vash_8-9 volcanic ash dispersion (Figure 3) shows that the volcanic ash dispersion moved to the southeast at an altitude of $700 \mathrm{mb}$ and to the southwest at an altitude of $250 \mathrm{mb}$. These findings confirmed the pervious study that analyzed the same Sinabung eruption using satellite-based observation data from the Himawari satellite. Pratama et al. (2019) also found that the volcanic ash was seen spreading westward which then turns to the south. The volcanic ash trajectory at 13:40 UTC began to dissipate to the southwest from the Sinabung location with the trajectory of the distribution of volcanic ash shows compatibility with the southwestward wind at the $200 \mathrm{mb}$ pressure level.

The analysis shows that there were differences in the dispersion direction of vash_6 (Figure 2b, 2c, 2d) and vash_8-9 (Figures 3b, 3c, 3d) at an altitude of $700 \mathrm{mb}$ on 9 June 2019 at 15 to 23 UTC. At that time the wind was moving to the southeast in the same direction with the vash_8-9 dispersion. On the

Table 4. Comparisons between WRF-chem and Upper-air observation at Kualanamu Airport, North Sumatera on 9 June 2019

\begin{tabular}{|c|c|c|c|c|c|c|c|c|}
\hline \multirow{3}{*}{$\begin{array}{l}\text { Pressure } \\
\text { Levels }\end{array}$} & \multicolumn{4}{|c|}{ Upper-air observations } & \multicolumn{4}{|c|}{ WRF-Chem simulations } \\
\hline & \multicolumn{2}{|l|}{$00 \mathrm{UTC}$} & \multicolumn{2}{|c|}{12 UTC } & \multicolumn{2}{|c|}{00 UTC } & \multicolumn{2}{|c|}{12 UTC } \\
\hline & $\begin{array}{l}\text { Wind } \\
\text { speed } \\
\text { (knots) }\end{array}$ & $\begin{array}{l}\text { Wind } \\
\text { direction } \\
\text { (degrees) }\end{array}$ & $\begin{array}{l}\text { Wind } \\
\text { speed } \\
\text { (knots) }\end{array}$ & $\begin{array}{l}\text { Wind } \\
\text { direction } \\
\text { (degrees) }\end{array}$ & $\begin{array}{l}\text { Wind } \\
\text { speed } \\
\text { (knots) }\end{array}$ & $\begin{array}{l}\text { Wind } \\
\text { direction } \\
\text { (degrees) }\end{array}$ & $\begin{array}{l}\text { Wind } \\
\text { speed } \\
\text { (knots) }\end{array}$ & $\begin{array}{l}\text { Wind } \\
\text { direction } \\
\text { (degrees) }\end{array}$ \\
\hline 250 & 29 & 55 & 22 & 60 & 18 & 55 & 20 & 66 \\
\hline 300 & 23 & 65 & 19 & 80 & 14 & 62 & 19 & 91 \\
\hline 600 & 3 & 175 & 2 & 305 & 3 & 165 & 1 & 51 \\
\hline 700 & 5 & 135 & 6 & 310 & 4 & 238 & 5 & 303 \\
\hline
\end{tabular}




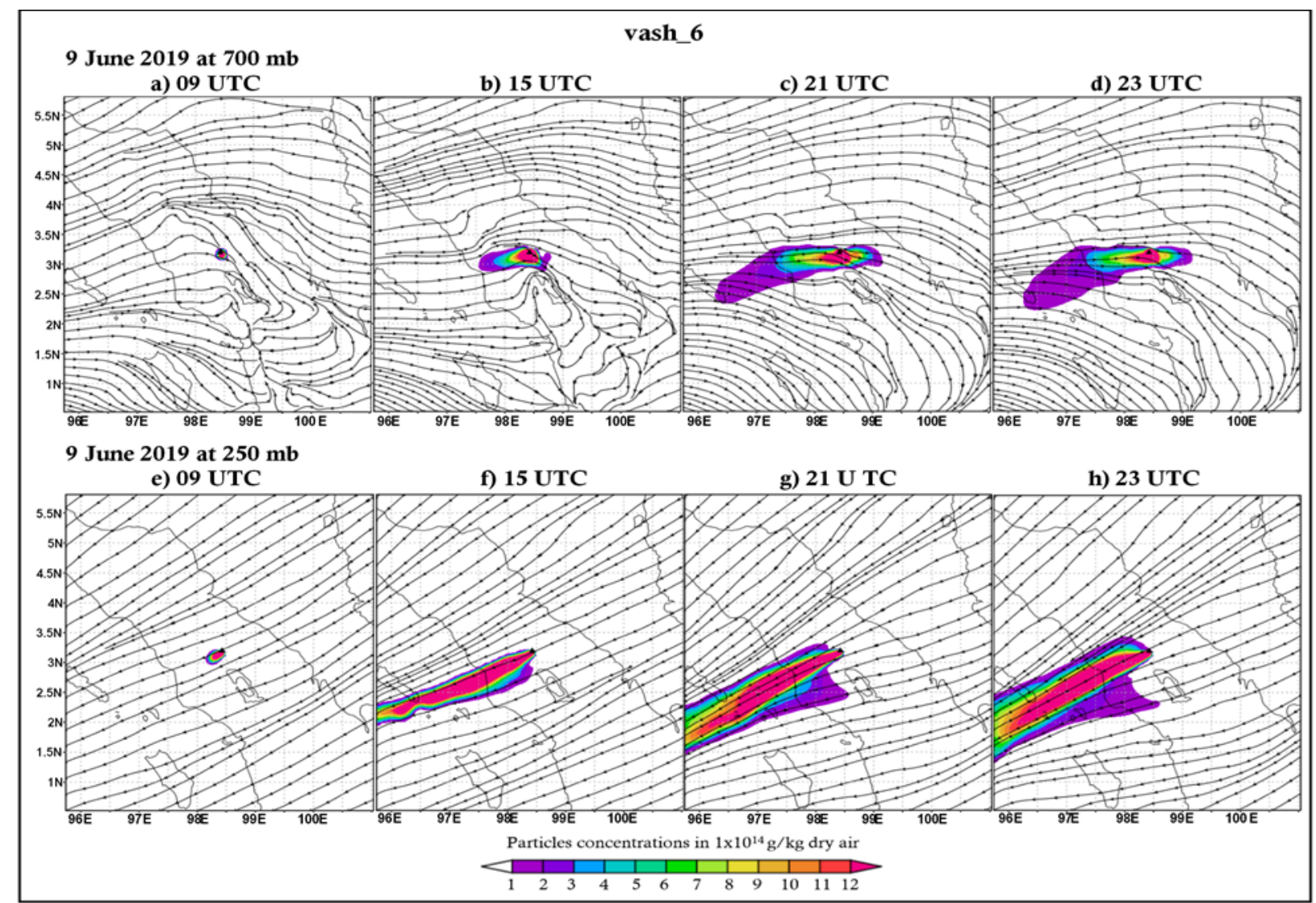

Figure 2. Dispersion of vash_6 based on WRF-chem simulations at $700 \mathrm{mb}$ and $500 \mathrm{mb}$ from 9 June 2019 at 09 UTC to 23 UTC

contrary, vash_6 seemed to be moving in the opposite direction to the west. The explanation why vash_6 move against the wind background is that actually there was an increase in the number of vash_6 depositions falling from the higher layers where the wind blew against the wind at the $700 \mathrm{mb}$, so that a misleading analysis may occur if a time-frame analysis is made without analyzing the vertical section of the vash_6.

Based on Figure 3, the farthest vash_8 and vash_8-9 ash dispersion at study time 09 to 23 UTC at an altitude of $700 \mathrm{mb}$ was $195 \mathrm{~km}$ to the southeast and at an altitude of $250 \mathrm{mb}$ with a further dispersion of more than $270 \mathrm{~km}$ to the southwest across the boundary of the modeling domain. The farthest vash_6 ash dispersion at an altitude of $700 \mathrm{mb}$ was $175 \mathrm{~km}$ to the west and at an altitude of $250 \mathrm{mb}$, the most distant dispersion was more than $270 \mathrm{~km}$ which also exceeded the boundary of the modeling domain.

According to Woods et al. (1995), it is not only the wind that affects the direction and dispersion of volcanic ash but also there are other factors such as the height of the eruption column and the size of the particles. Different volcanic ash dispersion patterns appear for different particle sizes because the falling velocity of volcanic ash particles increases with the particle size as a result of gravity. The smaller particles last longer in the top layer of the troposphere. On the other hand, the larger ash particles fall faster and are carried away by the wind at high speed. Therefore, at the start of the eruption, they were more scattered than the finer particle sizes. Meanwhile, a higher eruption column will make the ash particles to be injected higher to the upper layer of the troposphere so that the ash dispersion will be even wider.

In the same wind conditions at the $700 \mathrm{mb}$ layer, there is a difference in direction between vash_6 and vash_8-9 ash. The smaller size particles (vash_8-9) move with the wind, but not the larger ones (vash_6). This means that the dispersion of volcanic ash varies for different particle sizes. Meanwhile, at a higher layer of about $250 \mathrm{mb}$, volcanic ash moves faster and farther than the lower surface. Therefore, it is very possible that the cause of the dispersion of volcanic ash to explore further was due to the upper wind, this confirms study done by Sari (2015), which states that the upper wind dominates the movement of volcanic ash. The $250 \mathrm{mb}$ or $34,000 \mathrm{ft}$ layer which is at the top of the troposphere and below the tropopause also has the fastest wind speeds among the other layers beneath it, so the wind can push the volcanic ash to disperse further (International Civil Aviation Organization, 2007). 


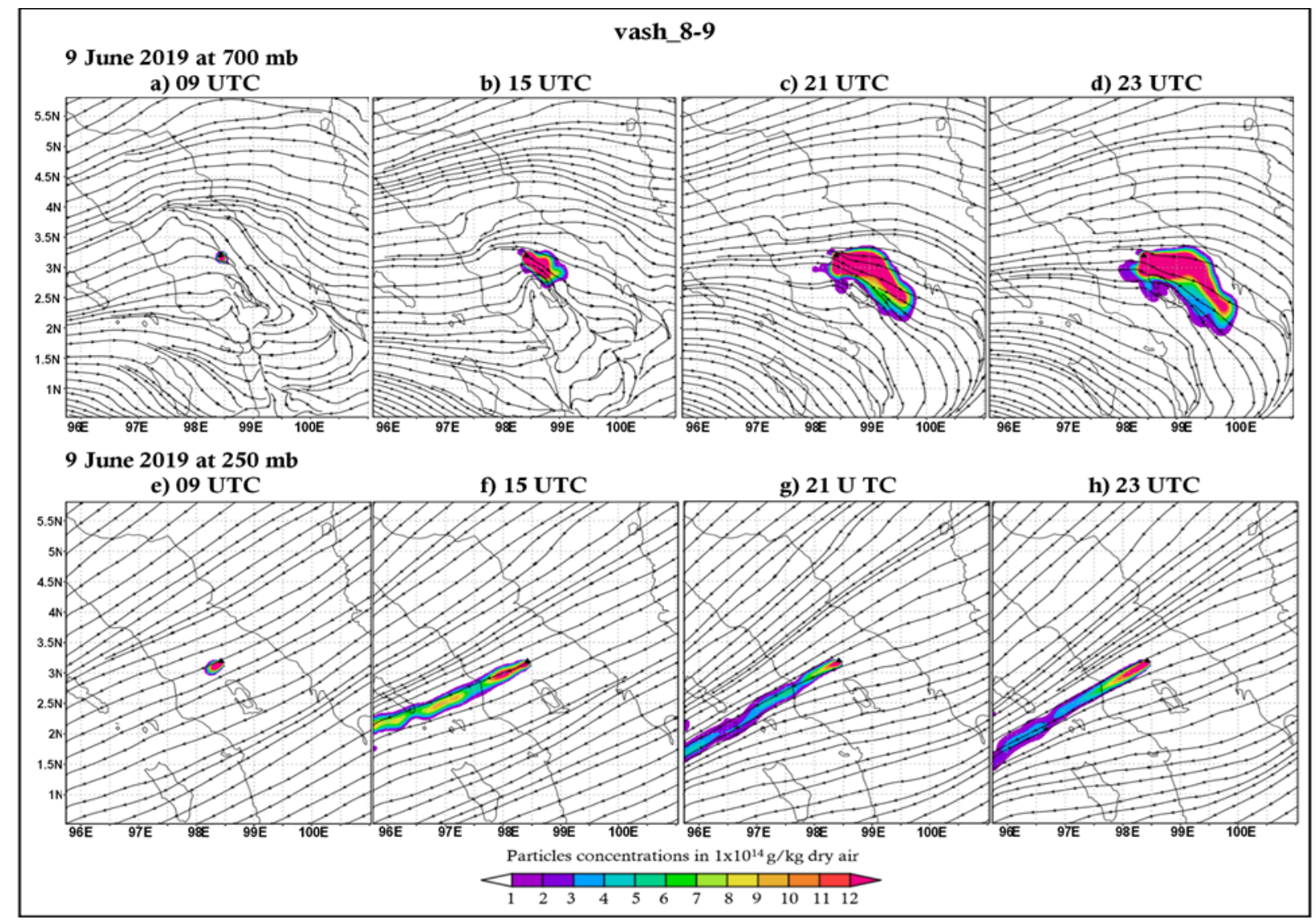

Figure 3. Dispersion of vash_8-9 based on WRF-chem simulations at $700 \mathrm{mb}$ and $500 \mathrm{mb}$ from 9 June 2019 at 09 UTC to 23 UTC

The vertical distribution of volcanic ash obtained from WRF-Chem processing can determine the height of the volcanic ash column by observing a layer that is similar in nature to the umbrella area (Figure 4). The elevation of Mount Sinabung is approximately 2,460 $\mathrm{m}$ which is equivalent to an altitude of $750 \mathrm{mb}$ in the WRF-Chem model. Therefore, volcanic ash that was below an altitude of 750 $\mathrm{mb}$, might come from volcanic ash debris caused by the eruption.

In the case of 9 June 2019, the ash dispersion of vash_8-9 (Figures 4a, 4b, 4c) and vash_6 (Figures $4 \mathrm{~d}, 4 \mathrm{e}, 4 \mathrm{f})$ show that the umbrella region as the peak of the eruption column is at the $300 \mathrm{mb}$ in the WRF-Chem model. Both of these parameters show that the ash dispersion moved radially and dominantly in one direction, i.e. westward. Thus, from this analysis, it was found that the column height was about $16 \mathrm{~km}$. Thus, it is in the umbrella region that needs more attention from the airlines, because this area is contaminated by volcanic ash which is dangerous for flights with high concentrations.

Even though the umbrella region was at the $300 \mathrm{mb}$ layer on the 9 June 2019 case, it was found that the dispersion of volcanic ash was able to spread higher than the eruption column. This was possibly caused by upper winds, particle size, and the force of the eruption. The simulations with WRF-Chem show that the vertical distribution of volcanic ash, in this case, exceeded $100 \mathrm{mb}$ layer in height, reaching the stratosphere.

Validation was carried out to evaluate the validity of the WRF-Chem simulation in this case. The simulation results were compared with a report from the VAAC-Darwin. Based on Figure 5, it can be seen that there was a similarity between the distribution of volcanic ash from the VAAC information and the output from WRF-Chem. Based on the VAAC report, the 9 June 2019 Sinabung Eruption was categorized as a high-level eruption with the warning up to flight level (FL) 550 or 55,000 feet (16.7 km) in height. VAAC information also reported that volcanic ash was seen moving to the southeast at 10 UTC at FL 14,000 feet or FL 140. Then, at 16 UTC the volcanic ash dispersion was seen in the southeast of Mount Sinabung, indicating there is an agreement with the WRF-Chem output at $600 \mathrm{mb}$ altitude. However, based on the WRF-Chem output at 16 UTC, the volcanic ash, apart from spreading to the southeast, was also seen starting to spread westward. 


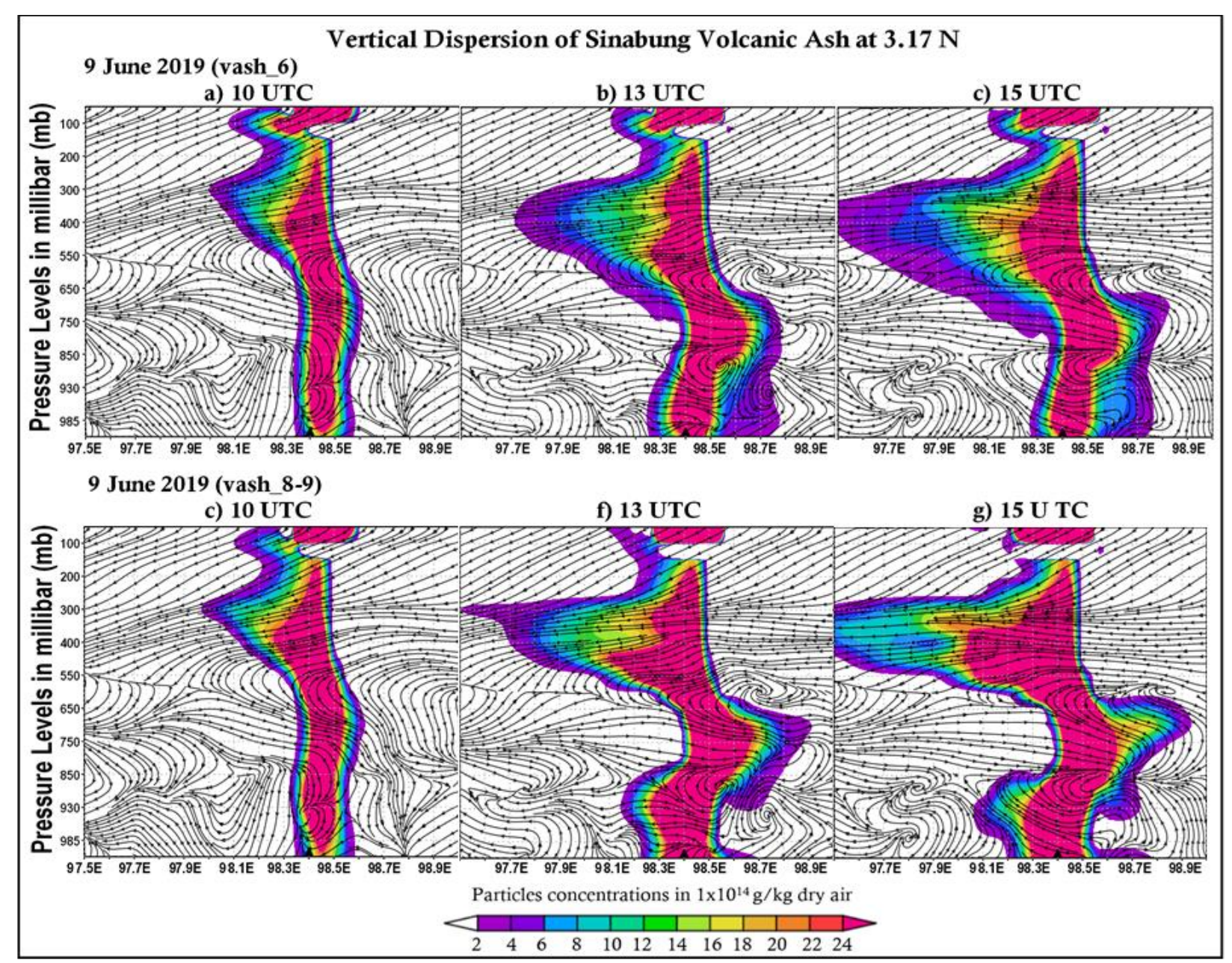

Figure 4. Vertical cross section of the Sinabung volcanic ash column of vash_6 and vash_8-9 from 9 June 2019 at 10 UTC to 15 UTC

At 20 UTC (Figure 6), VAAC information showed the spread of volcanic ash at an altitude of $30,000 \mathrm{ft}$ (FL 300) in the west of Mount Sinabung. The WRF-Chem simulations also indicate that volcanic ash was in the west of Mount Sinabung but moving towards the southwest. Then at an altitude of 14,000 ft (FL 140), it appears that the dispersion was moving to the southeast, in the WRF-Chem simulations, most of the volcanic ash is in the southeast of Mount Sinabung. However, the movement of the volcanic ash was dominant to the west.

In Figures 5 and 6, the parts with a high concentration of volcanic ash (red areas) are areas that should be avoided by aircraft. Based on the schematic diagram illustrated by Self and Walker that the area in addition to the high concentration of volcanic ash which is dangerous to aircraft engines, there is also local turbulence and high vertical velocity (Self \& Walker, 1994). The vertical velocity at the eruption column is about $50-200 \mathrm{~m} / \mathrm{s}$ (Woods, 1988). There are three types of eruptions, i.e., Plinian, Vulcanian/Sub-Plinian, and Vulcanian/Strombolian or Surtseyan eruptions in the hazardous area of volcanic ash dispersion scheme as mentioned in Self and Walker (1994). Sinabung is included in the Strombolian category (Sinuhaji et al., 2018). This scheme categorizes that the Strombolian eruption has an eruptive peak of about 26,000 to $33,000 \mathrm{ft}$, an average increase in the column eruption of $15-35 \mathrm{ft} / \mathrm{s}$, a low-medium ash concentration, fewer small particles, and a low potential for endangering the flight path (Self \& Walker, 1994). However, the case on 9 June 2019 shows that the maximum height of the eruption column exceeds $16 \mathrm{~km}$ or around 55,000 ft. In the case on 9 June 2019 at $10 \mathrm{UTC}$, the height of volcanic ash reached $150 \mathrm{mb}$ or the equivalent of $44,300 \mathrm{ft}$ within 32 minutes based on VONA report after the eruption began. This means that the average increase in the eruption column is $23 \mathrm{ft} / \mathrm{s}$. For the concentration category it is not explained in detail what the concentration value is for the low, medium and high category in the scheme.

Referring to a study by Alexander (2013), the threshold of volcanic ash concentrations that can cause serious damage to the engine is equal to or more than $2,000 \mu \mathrm{g} / \mathrm{m}^{3}$. If we compared with the concentration of volcanic ash eruptions on 9 June 2019, which had a maximum value of more than 


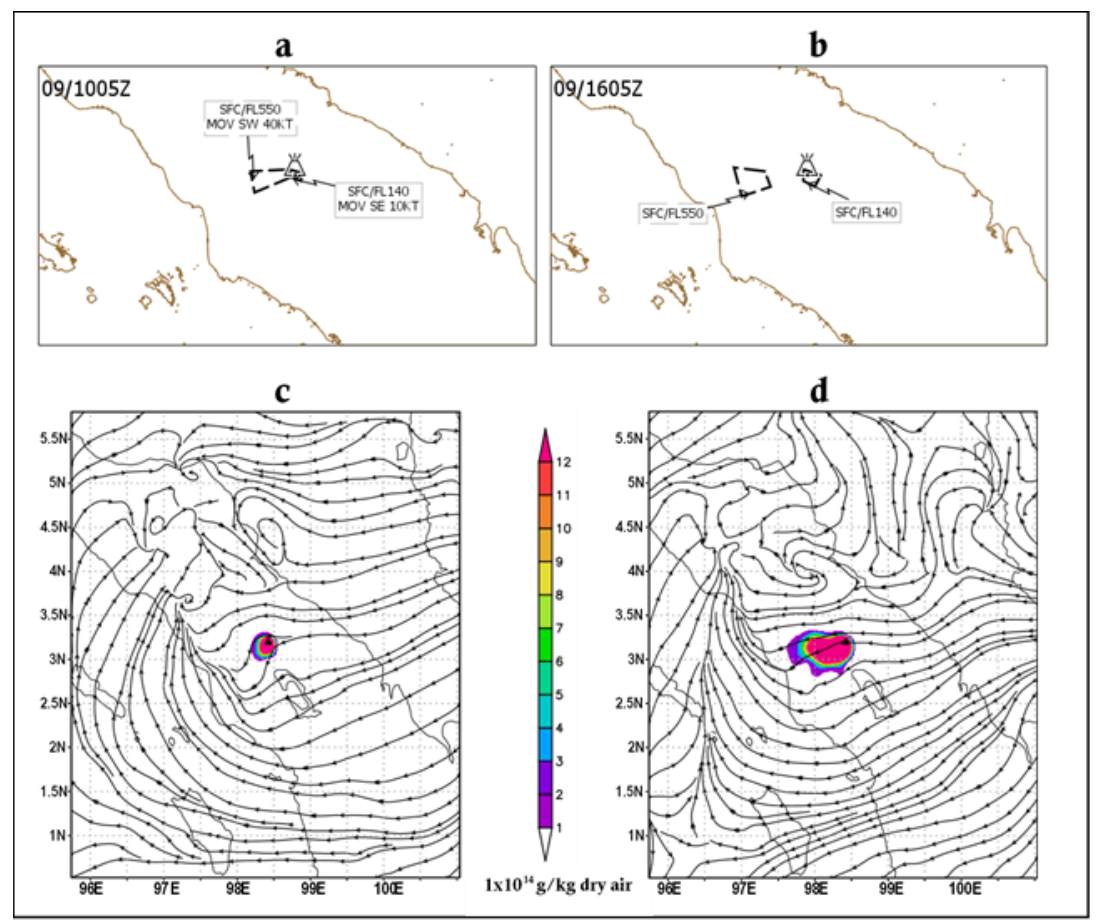

Figure 5. a. VAAC Report 9 June 2019 at FL 140 (10.05 UTC); b. VAAC Report 9 June 2019 at FL 140 (16.05 UTC); c. Dispersion of vash_6 at $600 \mathrm{mb}$ (10.00 UTC); d. Dispersion of vash_8-9 at 600 $\mathrm{mb}(16.00 \mathrm{UTC})$

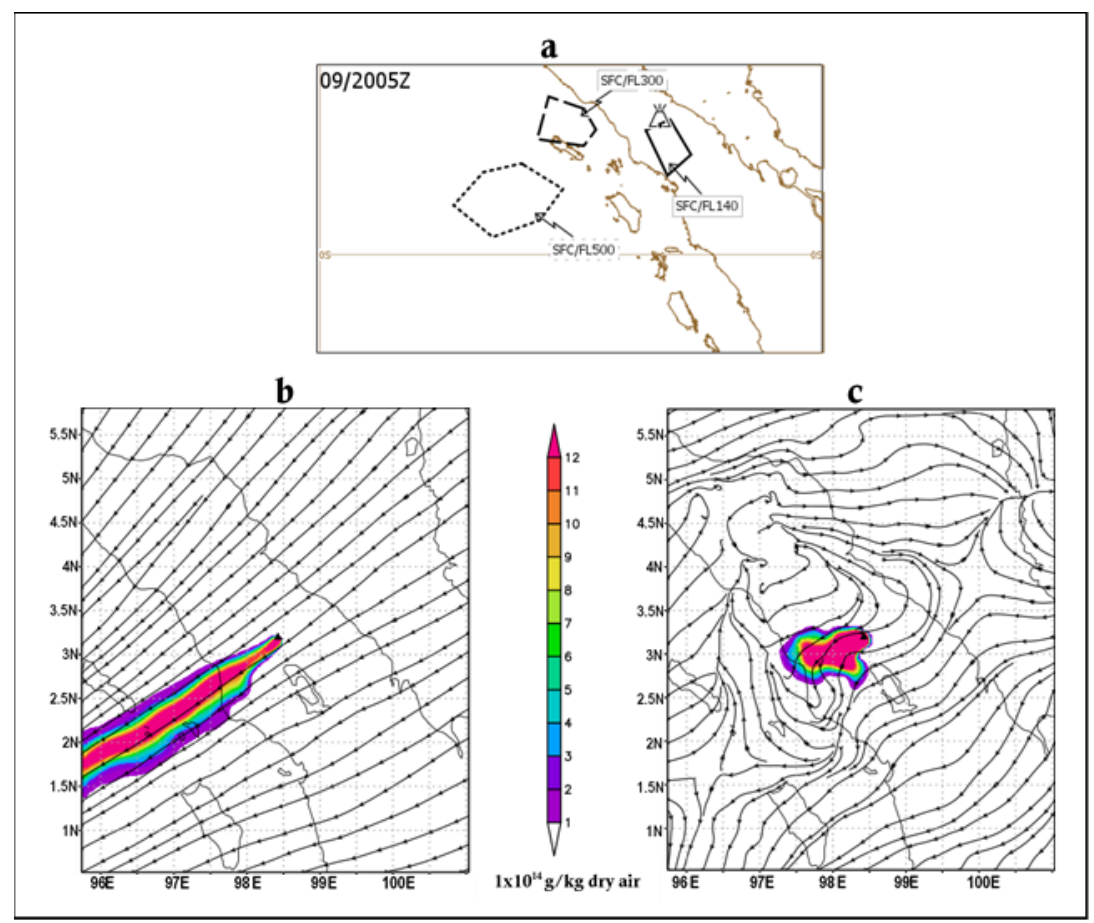

Figure 6. a. VAAC Report June 9; 2019 at 140 FL and 300 FL (20.00 UTC); b. Dispersion of vash_6 at $300 \mathrm{mb}$ (20.00 UTC); c. Dispersion of vash_8-9 at $600 \mathrm{mb}$ (20.00 UTC)

$24 \times 10^{20} \mu \mathrm{g} / \mathrm{kg}$ which is equivalent to $59.76 \times 10^{26} \mu \mathrm{g} / \mathrm{m}^{3}$ based on the density value of volcanic ash of $2.49 \mathrm{~g} / \mathrm{cm}^{3}$ (Vogel et al., 2017), this value is much greater than the volcanic ash concentration threshold that has been recommended. However, the effect of the eruption on the case of 9 June 2019 did not result in the closure of Kualanamu Airport (the closest airport to Mount Sinabung). The main cause of this is the direction of volcanic ash from the Sinabung eruption did not move towards the airport and its dispersion area did not interfere with the flight route to Medan City, where most airlines are on routes over the western ocean of Sumatera. 


\section{Conclusions}

The Sinabung eruption on 9 June 2019 with an observed column height of more than $16 \mathrm{~km}$ above sea level, was included in the red code category based on the VONA report. The WRF-Chem model was able to simulate the horizontal and vertical dispersion of volcanic ash and estimate the height of the eruption column. The VAAC report also reported the dispersion of this eruption, and we found that there was a good concordance between the VAAC report and the dispersion from the WRF-Chem simulation. The simulations show that at a higher surface, volcanic ash moves faster and farther than a lower surface. We found that the cause of volcanic ash to spread further was due to the upper layer winds blowing harder than the winds in the lower layers. However, there was a difference in the distribution direction at an altitude of $700 \mathrm{mb}$ that vash_6 (31.25-62.5 $\mu \mathrm{m})$ moved against the wind direction, while vash_8-9 (3.9065-15.625 $\mu \mathrm{m})$ moved in the same direction as the wind direction. There is the possibility that a larger ash size requires a larger wind speed to make the ash move and scatter. However, the discussion regarding the wind speed effect is beyond the limitation of this study so that it cannot be discussed further in this study. Further research can be conducted to predict the area contaminated by those two important parameters using the WRF-Chem model.

\section{Acknowledgments}

The authors would like to thank the Indonesian Institute of Sciences (LIPI) for permitting to access of high-performance computers (HPC) as part of the numerical modeling of this research. Further thanks to the Agency for Meteorology, Climatology, and Geophysics (BMKG) and the School of Meteorology, Climatology, and Geophysics (STMKG) for their support for this research.

\section{References}

Alexander, D. (2013). Volcanic ash in the atmosphere and risks for civil aviation: A study in European crisis management. International Journal of Disaster Risk Science, 4(1), 9-19. doi:10.1007/s13753013-0003-0

Bursik, M. (2001). Effect of wind on the rise height of volcanic plumes. Geophysical Research Letters, 28(18), 3621-3624. doi:10.1029/2001GL013393

Casadevall, T. J. (1994). The 1989-1990 eruption of Redoubt Volcano, Alaska: impacts on aircraft operations. Journal of Volcanology and Geothermal Research, 62(1-4), 301-316. doi:10.1016/03770273(94)90038-8

Crawford, A. M., Stunder, B. J., Ngan, F., \& Pavolonis, M. J. (2016). Initializing HYSPLIT with satellite observations of volcanic ash: A case study of the 2008 Kasatochi eruption. Journal of Geophysical Research: Atmospheres, 121(18), 10,786-710,803. doi:10.1002/2016JD024779

Devenish, B., Francis, P., Johnson, B., Sparks, R., \& Thomson, D. (2012). Sensitivity analysis of dispersion modeling of volcanic ash from Eyjafjallajökull in May 2010. Journal of Geophysical Research: Atmospheres, 117(D20). doi:10.1029/2011JD016782

Dunn, M. G. (2012). Operation of gas turbine engines in an environment contaminated with volcanic ash. Journal of Turbomachinery, 134(5). doi:10.1115/1.4006236

Egan, S. D., Stuefer, M., Webley, P. W., Lopez, T., Cahill, C. F., \& Hirtl, M. (2020). Modeling volcanic ash aggregation processes and related impacts on the April-May 2010 eruptions of Eyjafjallajökull volcano with WRF-Chem. Natural Hazards and Earth System Sciences, 20(10), 27212737. doi:10.5194/nhess-20-2721-2020, 2020.

Fatkhuroyan, F., \& Wati, T. (2017). Pemantauan Sebaran Abu Vulkanik Menggunakan Penginderaan Jauh Satelit Himawari-8 dan AURA/OMI (Ozone Mapping Instrument). Majalah Ilmiah Globe 19(1), 33-44. doi:10.24895/MIG.2017.19-1.539

Folch, A., Costa, A., \& Basart, S. (2012). Validation of the FALL3D ash dispersion model using observations of the 2010 Eyjafjallajökull volcanic ash clouds. Atmospheric Environment, 48, 165183. doi:10.1016/j.atmosenv.2011.06.072

Gordeev, E., \& Girina, O. (2014). Volcanoes and their hazard to aviation. Herald of the Russian Academy of Sciences, 84(1), 1-8. doi:10.1134/S1019331614010079

Grell, G. A., Peckham, S. E., Schmitz, R., McKeen, S. A., Frost, G., Skamarock, W. C., \& Eder, B. (2005). Fully coupled "online" chemistry within the WRF model. Atmospheric Environment, 39(37), 6957-6975. doi:10.1016/j.atmosenv.2005.04.027 
Guffanti, M., \& Tupper, A. (2015). Volcanic ash hazards and aviation risk. In Volcanic hazards, risks and disasters (pp. 87-108): Elsevier.

International Civil Aviation Organization. (2007). Manual on volcanic ash, radioactive material, and toxic chemical clouds (Second ed.): International Civil Aviation Organization (ICAO).

Lee, S.-K., Ryu, G.-H., Hwang, E.-H., Choi, J.-K., \& Lee, C.-W. (2014). Predicting the extent of the volcanic ash dispersion using GOCI image and HYSPLIT model-A case study of the 17 Sep, 2013 eruption in SAKURAJIMA volcano. Korean Journal of Remote Sensing, 30(2), 303-314. doi:10.7780/kjrs.2014.30.2.12

Mastin, L. G., Guffanti, M., Servranckx, R., Webley, P., Barsotti, S., Dean, K., . . Rose, W. I. (2009). A multidisciplinary effort to assign realistic source parameters to models of volcanic ash-cloud transport and dispersion during eruptions. Journal of Volcanology and Geothermal Research, 186(1-2), 10-21. doi:10.1016/j.jvolgeores.2009.01.008

Miller, T. P. (1999). Ash Hazards to Aviation. Encyclopedia of volcanoes, 915.

Pandjaitan, B. S., Susilowati, A., \& Pandjaitan, A. (2016). Pemanfaatan data multi kanal satelit cuaca himawari 8 dengan menggunakan beberapa teknik RGB untuk mendeteksi debu vulkanik (Studi kasus: Letusan Gunung Bromo pada bulan Januari 2016). Paper presented at the Seminar Nasional Penginderaan Jauh.

Prata, F., \& Rose, B. (2015). Volcanic ash hazards to aviation. In The Encyclopedia of Volcanoes (pp. 911934): Elsevier.

Pratama, D. A., Saputro, M. B., Masruri, M. F. I., Siwi, N. D. P., Fajarianti, R., \& Margiono, R. (2019). Deteksi Sebaran Debu Vulkanik Menggunakan Citra Satelit Himawari-8 (Studi Kasus Gunung Sinabung 9 Juni 2019). Bulletin of Scientific Contribution: GEOLOGY, 17(3), 187-192.

Ryan, M., \& Pratama, K. R. (2019). Identifikasi trajektori debu vulkanik letusan Gunung Gamalama dengan Hysplit dan metode RGB pada citra satelit Himawari 8. Jurnal Meteorologi Klimatologi dan Geofisika, 4(2), 29-34. doi:10.36754/jmkg.v4i2.44

Sari, F. P. (2015). Identifikasi dan monitoring sebaran abu vulkanik Gunung Raung (analisis kejadian 4 - 14 Juli 2015). Prosiding Workshop Operasional Satelit Cuaca 2015, 237-246.

Saxby, J., Beckett, F., Cashman, K., Rust, A., \& Tennant, E. (2018). The impact of particle shape on fall velocity: Implications for volcanic ash dispersion modelling. Journal of Volcanology and Geothermal Research, 362, 32-48. doi:10.1016/j.jvolgeores.2018.08.006

Self, S., \& Walker, G. P. (1994). Ash clouds: characteristics of eruption columns. US Geological Survey Bulletin, 2047, 65-74.

Sinuhaji, P., Sembiring, T., Maghfirah, A., Piliang, A. F., \& Nababan, S. M. (2018). Analysis of Composition; Topography of Volcanic Materials Erupted from Mount Sinabung, Karo Regency, Indonesia. Journal of Physics : Conference Series, 1116(3). doi:10.1088/1742-6596/1116/3/032035

Song, W., Hess, K. U., Damby, D. E., Wadsworth, F. B., Lavallée, Y., Cimarelli, C., \& Dingwell, D. B. (2014). Fusion characteristics of volcanic ash relevant to aviation hazards. Geophysical Research Letters, 41(7), 2326-2333. doi:10.1002/2013GL059182

Steensen, T., Stuefer, M., Webley, P., Grell, G., \& Freitas, S. (2013). Qualitative comparison of Mount Redoubt 2009 volcanic clouds using the PUFF and WRF-Chem dispersion models and satellite remote sensing data. Journal of Volcanology and Geothermal Research, 259, 235-247. doi:10.1016/j.jvolgeores.2012.02.018

Stenchikov, G., Ukhov, A., \& Ahmadov, R. (2017). Simulation of the initial stage of the Mt. Pinatubo eruption using the coupled meteorology-chemistry WRF-Chem model. Paper presented at the EGU General Assembly Conference Abstracts.

Stohl, A., Prata, A., Eckhardt, S., Clarisse, L., Durant, A., Henne, S., . . . Seibert, P. (2011). Determination of time-and height-resolved volcanic ash emissions and their use for quantitative ash dispersion modeling: the 2010 Eyjafjallajökull eruption. Atmospheric Chemistry and Physics, 11(9), 4333-4351. doi:10.5194/acp-11-4333-2011

Stuefer, M., Freitas, S., Grell, G., Webley, P., Peckham, S., \& McKeen, S. (2012). Inclusion of ash and $\mathrm{SO} 2$ emissions from volcanic eruptions in WRF-Chem: development and some applications. Geoscientific Model Development Discussions, 5(3), 2571-2597. doi:10.5194/gmdd-5-2571-2012

Tadini, A., Roche, O., Samaniego, P., Guillin, A., Azzaoui, N., Gouhier, M., . . . Bernard, B. (2020). Quantifying the uncertainty of a coupled plume and tephra dispersal model: PLUME-MOM/HYSPLIT simulations applied to Andean volcanoes. Journal of Geophysical Research: Solid Earth, 125(2), e2019JB018390. doi:10.1029/2019JB018390 
Vogel, A., Diplas, S., Durant, A. J., Azar, A. S., Sunding, M. F., Rose, W. I., . . Stohl, A. (2017). Reference data set of volcanic ash physicochemical and optical properties. Journal of Geophysical Research: Atmospheres, 122(17), 9485-9514. doi:10.1002/2016JD026328

Wati, K. S., Astiduari, I. P. P., \& Wiguna, P. P. H. (2017). Pemanfaatan Citra Satelit Himawari-8 dan Model WRF-CHEM untuk Memantau Sebaran Debu Vulkanis (Studi Kasus: Erupsi Gunung Barujari, 4 November 2015) Utilization of Himawari-8 Satellite and WRF-CHEM Model for Monitoring Volcanic Ash Dispersion (Case Study: Mt. Barujari Eruption. Prosiding Seminar Nasional Penginderaan Jauh 2017.

Webley, P. W., Steensen, T., Stuefer, M., Grell, G., Freitas, S., \& Pavolonis, M. (2012). Analyzing the Eyjafjallajökull 2010 eruption using satellite remote sensing, lidar and WRF-Chem dispersion and tracking model. Journal of Geophysical Research: Atmospheres, 117(D20). doi:10.1029/2011JD016817

Woods, A. W. (1988). The fluid dynamics and thermodynamics of eruption columns. Bulletin of volcanology, 50(3), 169-193. doi:10.1007/BF01079681

Woods, A. W., Holasek, R. E., \& Self, S. (1995). Wind-driven dispersal of volcanic ash plumes and its control on the thermal structure of the plume-top. Bulletin of volcanology, 57(5), 283-292. doi:10.1007/BF00301288

Yudistira, R., Indah, S., \& Agung Hari, S. (2020). Pemanfaatan model WRF-Chem dalam analisis sebaran abu vulkanik Gunung Merapi (Erupsi tanggal 23 Maret 2020). Jurnal Meteorologi Klimatologi dan Geofisika, 6(3), 15-22. doi:10.36754/jmkg.v6i3.137 